\title{
The Effectiveness of Teaching Materials Based on Local Culture on 7th Grade Students in Junior High School Sipirok
}

\author{
Muhammad Riswan Nasution', Wisman Hadi $^{2}$, Syahnan Daulay ${ }^{2}$ \\ ${ }^{1}$ Master Student in State University of Medan, Medan, Indonesia \\ ${ }^{2}$ Lecturer in State University of Medan, Medan, Indonesia \\ m_riswannasution@yahoo.co.id
}

\section{Abstract}

The study deals with the effectiveness of teaching materials based on local culture on 7th grade students in junior high school Sipirok. The study was conducted at one of Junior High Schools 1 in Sipirok located in South Tapanuli Regency. Student learning outcomes are obtained by providing a trial test using instructional materials that have been developed which aims to see the extent to which increased student understanding of the Sipirok local culturebased text description learning material by using teaching materials developed in this study. Student learning outcomes based on pretest and posttest show the difference in the difference from pretest to posttest the score obtained 10.42 with an average pretest 75.65 on the criteria of "good" and an average posttest of 90.8 on the criteria of "very good". It can be concluded that learning using on Sipirok local culture-based text descriptions can improve student learning outcomes in Indonesian language subjects especially description text material.

\section{Keywords}

teaching material; local

culture; Sipirok; student

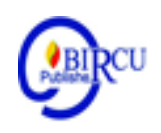

\section{Introduction}

Local culture is a view of life and science as well as various life strategies in the form of activities carried out by local communities in answering various problems in filling their needs. In a foreign language, it is often conceptualized as a local policy of "local wisdom" or "local knowledge" or local intelligence "local genious". According to Lehman, Himstreet, Culture is a bunch of life experiences that exist in their own communities.

Community life experience alone is very many and varied, including in how the behavior and beliefs or beliefs of the community itself. Whereas Mitchel believes that local culture is a set of scores or rules that apply as beliefs, standards, knowledge, moral law to the behavior of individuals and society that determine how a person acts, feels, and sees himself as well as others. In education, local culture can take advantage of local excellence in economic aspects, arts and culture, human resources, language, information and communication technology, ecology, and others into the school curriculum which ultimately benefits the development of student competencies that can be utilized for global competition.

One example of local culture that can be used in learning for VII grade students of junior high school at South Tapanuli School. Students can also develop their character through local culture. This was made clear by Sibarani (2012: 175), that an understanding of the concept of local culture is necessary to be useful in managing social life. The ultimate goal of the study of local culture is its application in shaping the personality of the younger generation as a socio-cultural capital, specifically for the two welfare improvements of future generations. 
For the purpose of peace, local culture functions as a source of goodness or good personality in interacting so as to create peace in that interaction, while for the purpose of welfare, local culture functions as a source of creativity, deposit of cultural industries, and motivation for success for people's prosperity, both goals of local culture it ultimately functions to shape the character of the younger generation who have personalities and characters who love peace and well-being. Local culture ultimately functions as the formation of good personality and character, especially for the eighth grade students of junior high school to arrange their way of thinking and acting in their lives.

\section{Review of Literature}

\subsection{The Definition of Teaching Materials}

Teaching material is a process, method, and act of developing science and technology that utilizes rules with the aim of improving the functions, benefits, and applications of science and technology in physical form containing subject matter, methods, limitations and ways of evaluating that are designed in such an attractive way that makes it easier for teachers to deliver a learning material.

According to Suroso (2018) he learning process on campus is an interaction event involving students, educators by implementing curriculum designs that are applied to the achievement of the acquisition of knowledge, mastery of certain skills, and the formation of good attitudes and self-confidence in students. The learning process is expected to continue to be able to develop and be able to produce innovative learning products that are able to compete and be able to answer challenges and be able to meet educational needs in the community.

From some of the above opinions, it can be concluded that teaching materials are materials or teaching aids for teachers both information, tools, or systematically compiled text that is used to help the teacher / instructor in carrying out teaching and learning activities in order to achieve the expected learning objectives.

The purpose of the preparation of teaching materials is:

a. Provide teaching materials that are in accordance with the demands of the curriculum taking into account the needs of students, namely teaching materials that are in accordance with the characteristics and social settings or environment of students.

b. Facilitating the teacher in carrying out learning.

c. Help students in obtaining alternative teaching materials in addition to text books that are sometimes difficult to obtain. Principles for the Selection of Teaching Materials

There are several principles that need to be considered in the preparation of teaching materials or learning materials, namely:

\section{a. The Principle of Relevance}

The principle of relevance means interconnection. Learning material should be relevant or related to the achievement of competency standards and basic competencies. For example, if the competency that is expected to be mastered by students is in the form of memorizing facts, then the learning material taught must be in the form of facts or memorization material.

\section{b. The Principle of Consistency}

The principle of consistency means regularity. If there are four kinds of basic competencies that must be mastered by students, then the teaching materials that must be 
taught must also include four types. For example the basic competencies students must master are the operations of numbers which include addition, subtraction, multiplication, and division, so the material taught must also include addition, subtraction, multiplication, and division techniques.

\section{c. The Principle of Adequacy}

The principle of adequacy means that the material taught should be sufficient in helping students master the basic competencies taught. Material must not be too little, and must not be too much. If it is too little it will not help to achieve the standard of competence and basic competence. Conversely, if too much will waste time and effort unnecessarily to learn it.

\subsection{The Definition of Text Description}

Description text is a text where the main idea is conveyed by clearly describing the object, place, or event that is being the topic or theme to the reader. So that the reader seems to feel firsthand what is being expressed in the text. Wiyanto (2014: 115), argues "Description is to describe a discourse that seeks to present a thing or object of conversation as if the reader saw the object for himself as if it was in front of the eyes of the readers". While Winarsih (2008: 325), states that the description is also called a painting. The point is an essay that contains the painting or depiction of an object. This is done so that the reader can see, hear, and feel for themselves, the thing described.

Darmayanti (2007) states the text or paragraph description is a reading text that is prepared to describe or to describe an experience, hearing, touch, smell, and feelings about a situation or problem. In making the description text, the writer tries to move his impressions, observations, and feelings to the reader by conveying the nature and details found from the object. Darmayanti (2008) states the description text is a text that describes an object based on observations. Imaging is meant to see, hear, smell, and feel. The reader is expected to be able to equate the image within himself with the image of the author. Paujiyanti (2014) states the description text is a text that describes an object with the aim that readers seem to be able to see, hear, or feel the object described by the author in the paragraph. The object described can be in the form of goods, objects, or places. According to Henry Guntur Tarigan (1994), a description is a writing that can describe a story that aims to invite the reader to be able to understand, feel and enjoy the objects being discussed such as moods, activities and so on.

\subsection{Definition of Local Culture}

Culture is a whole system of ideas, actions and results of human work in the life of society that is made into the property of humans by learning, the term local culture (local wisdom) consists of two words, namely local culture (wisdom) which means wisdom, while the local word (local) is local. Therefore local culture can be defined as local ideas and knowledge that are wise, full of culture, of good score, and virtuous.

According to Sibarani, (2014), local culture can be understood as cultural scores, traditional ideas, and local knowledge that is wise, full of wisdom, good score, and virtuous owned by community members in managing their social life. Local culture is obtained from cultural traditions or oral traditions because local wisdom is the content of oral traditions or cultural traditions that are passed down from generation to generation and are utilized to organize the social life of students in all areas of their lives. Local culture is the score of local culture that can be used to regulate the order of people's lives wisely or wisely. Fajarini (2014: 123) defines local culture as a way of life and knowledge and as a strategy in the form 
of activities carried out by local students in answering various problems in meeting their needs. The same thing also stated by Ridwan (2007: 28) which states that local culture can be understood as a human effort by using his mind (cognition) to act and behave towards something, object, or event that occurs in a particular space. The above understanding is arranged etymologically, where local culture is understood as a person's ability to use their minds to act or act as a result of an assessment of something, object, or event that occurs.

\subsection{History of Sipirok}

Sipirok was originally a sub-district in South Tapanuli Regency, North Sumatra Province. After Padangsidimpuan City was changed to Madya City (which was previously the capital of South Tapanuli Regency), then Sipirok changed to become the capital of South Tapanuli Regency. Since Sipirok became the capital of South Tapanuli Regency, a number of government offices in South Tapanuli Regency were moved from Padangsidimpuan City to Sipirok. This transfer was realized in mid-2014. A number of the offices were the Secretariat of South Tapanuli Regency Government, DPRD office, Regional Development Planning Agency (Bappeda), Health Office (Dinkes), Regional Financial and Asset Management Agency (BPKAD), Civil Service Police Unit (Satpol PP), and the Civil Registry Office and the Department of Labor.

Sipirok is one of the sub-districts, as well as the center of government in South Tapanuli Regency, North Sumatra, Indonesia. The distance from Medan to Sipirok is around $356 \mathrm{~km}$, or about 8- 9 hours by land transportation to the south. This sub-district is the birthplace of several national figures such as Merari Siregar, an author of Balai Pustaka force. Luat Siregar, mayor of Medan from 3 October 1945 to 10 November 1945. Lafran Pane Founder of the biggest student organization in Indonesia, the Islamic Student Association (HMI), Hariman Siregar, a major figure in the Student Movement who is remembered by history in the "MALARI" event and also Raja Inal Siregar (One of the founders of SMA Plus Marsipature Hutanabe South Tapanuli) who also initiated the term "Marsipature huta be" which means let's build our respective villages. The term was clearly intended for Sipirok native sons and daughters who were overseas to always remember and always help their brothers and sisters who were considered still lagging behind (education) compared to other regions at that time.

\section{Research Method}

The study was conducted at one of Junior High Schools 1 in Sipirok located in South Tapanuli Regency. The research is conducted in the school year 2018.-2019. The reason researchers chose this school as an example of local culture that can be used as learning is found in the symbol of South Tapanuli, so that cultural existence remains firm, students who are considered as the next generation need to be instilled a love of local culture, especially in Sipirok area.

\section{Discussion}

Student learning outcomes are obtained by providing a trial test using instructional materials that have been developed which aims to see the extent to which increased student understanding of the Sipirok local culture-based text description learning material by using teaching materials developed in this study. The trial was conducted in grade VII, amounting 
to 35 students by looking at the acquisition of the description text learning outcomes before using teaching materials (modules) and already using teaching materials.

Data analysis conducted on learning outcomes before using teaching materials in the form of Sipirok local culture-based text description learning material obtained an average score of $75.65 \%$ with "sufficient" assessment criteria. The results of the pretest score can be seen in appendix 10 . The average results of these scores indicate that the grades achieved by students in the description text material have reached expectations but need to be increased again. The frequency distribution of the pretest scores of the learning outcomes of the description text before using the module's teaching materials can be seen in table 1 below.

Table 1. Frequency Distribution of Pretest Description Text Score Learning Outcomes before Using the Module

\begin{tabular}{|l|l|l|}
\hline Interval & Frequency & Percentage \\
\hline $65-68$ & 2 & $5,71 \%$ \\
\hline $69-72$ & 13 & $37,14 \%$ \\
\hline $73-76$ & 6 & $17,14 \%$ \\
\hline $77-80$ & 7 & $20 \%$ \\
\hline $81-84$ & 2 & $5,71 \%$ \\
\hline $85-88$ & 3 & $8,57 \%$ \\
\hline $89-92$ & 2 & $5,71 \%$ \\
\hline $\boldsymbol{\Sigma}$ & $\mathbf{3 5}$ & $\mathbf{1 0 0}$ \\
\hline
\end{tabular}

Students who get the score of $65-68$ is amounted to 2 students or 5.71\%, who get the score of $69-72$ is 13 students or $37.14 \%$, who get the score of $73-76$ is 6 students or $17.14 \%$, who get the score of 77-80 is 7 students or $20 \%$, who get the score of $81-84$ is 2 students or $5.71 \%$, who get the score of $85-88$ is 3 students or $8.57 \%$, and who get a score of $89-92$ is 2 students or $5.71 \%$. The total number of students is 35 .

Data analysis conducted on learning outcomes after using teaching materials in the form of Sipirok local culture-based text description learning material obtained an average score of $90.8 \%$ with "excellent" assessment criteria. The results of the posttest score can be seen in the table. The average score results indicate that the scores achieved by students in the description text material are very good. The frequency distribution of posttest scores of the learning outcomes of the description text after using the module's teaching materials can be seen in table 2 below:

Table 2. Frequency Distribution of Posttest Score in Text Description Learning Outcomes after Using the Module

\begin{tabular}{|l|l|l|}
\hline Interval & Frequency & Percentage \\
\hline $80-82$ & 4 & $11,42 \%$ \\
\hline $83-85$ & 6 & $17,14 \%$ \\
\hline $86-88$ & 5 & $14,28 \%$ \\
\hline $89-91$ & 5 & $14,28 \%$ \\
\hline $92-94$ & 1 & $2,85 \%$ \\
\hline $95-97$ & 5 & $14,28 \%$ \\
\hline $98-100$ & 9 & $25,71 \%$ \\
\hline $\boldsymbol{\Sigma}$ & $\mathbf{3 5}$ & $\mathbf{1 0 0}$ \\
\hline
\end{tabular}


Students who get the score of $80-82$ is 4 students or $11.42 \%$, those who get the score of $83-85$ is 6 students or $17.14 \%$, those who get the score of $86-88$ is 5 students or $14.28 \%$, who get the score of $89-91$ is 5 students or $14.28 \%$, who get the score of $92-94$ is 1 person or $2.85 \%$, who get the score of $95-97$ is 5 students or amounting to $14.28 \%$, and who get the score of $98-100$ is 9 students or $25.71 \%$. The total number of students is 35 .

After learning using the description text material based on Sipirok local culture, student learning outcomes before and after using the teaching material experienced a significant increase that is $10.42 \%$ known the average score of students before (pretest) using teaching materials $75.65 \%$ and posttest score of $90.8 \%$. The following are the average scores of pretest and posttest.

Table 3. Summary of Pretest and Posttest Average Scores

\begin{tabular}{|l|l|l|l|}
\hline No & Group & Average Score & Deviation \\
\hline 1 & Before (pretest) & 75,65 & \multirow{2}{*}{10,42} \\
\hline 2 & After (posttest) & 90,8 & \\
\hline
\end{tabular}

The table above shows the difference in the difference from pretest to posttest score obtained 10.42 with an average pretest 75.65 on the criteria of "good" and an average posttest of 90.8 on the criteria of "very good". It can be concluded that learning using Sipirok local culture-based text description can improve student learning outcomes in Indonesian subjects especially description text material.

The results of the development of teaching materials obtained questionnaire results 91.67\% stated that they need teaching materials based on description text in the learning process to run more effectively and can be used as a learning tool individually by students. The results of the questionnaire were obtained based on the process of implementing teaching material development in stage I, namely carrying out a preliminary study.

The preliminary study was carried out by conducting a needs analysis (field survey) and literature survey. Based on the theory cited by Dahiya Sunita \& Ajeya Jha in the International Journal of Information Technology and Knowledge (2011: 263), needs analysis is the process of determining the results of a field survey obtained by distributing questionnaires to teachers and students at the school by first describing the definition of Sipirok local culture-based module on the questionnaire in order to have an overview of the questions in the questionnaire submitted. Questionnaires distributed to schools totaled 36 questionnaires from 35 students of VII grade and 1 teacher of Indonesian language.

The results of the needs analysis consist of 3 question options. First, ask about the introduction of students and teachers about the textual teaching material based on Sipirok local culture. The results obtained from these questions obtained by 18 students answered familiar with Sipirok local culture-based text description teaching material, while 17 students answered did not recognize Sipirok local culture-based text description teaching material. According to some students who stated that they were familiar with indigenous culture-based teaching materials, they thought that Sipirok local culture was still developing in the environment around students and students felt that they were very familiar with the stages of Sipirok's origins, so that they considered Sipirok local culture-based text description teaching material that was already very well known.

It is different from some other students who state that they are not familiar with the Sipirok local culture-based description text teaching material. According to some of the students the teaching materials used in the process of learning descriptive text use Indonesian 
textbooks produced by the Ministry of Education and Culture. The theme discussed in the description text learning material discusses learning to describe, so students do not know how the textual Sipirok local culture-based teaching material if it is associated with learning text description. In addition, a small number of students said they did not yet know what the origin of Sipirok local culture.

Then in the second question asks about whether Sipirok local culture-based description text teaching material has been used before by the teacher in the learning process. The results obtained from these questions were obtained by 3 students who answered using Sipirok local culture-based description text teaching materials in the process of learning text description, while 32 students answered never using Sipirok local culture-based description text teaching materials in the process of learning description text.

Based on the results of the statement above, the opinion expressed by students who responded to using Sipirok local culture-based description text teaching material stated that Sipirok local culture-based learning had been learned directly through the Sipirok Mandailing customs process in the environment around students, so students were very familiar with if related to description text learning, whereas for other students who answer have never used Sipirok local culture-based text description teaching material because students have never heard and know the theme of culture in the learning process, so it is interesting for students to know the text description material based on local culture Sipirok which in general has been very attached to the culture around students.

The third question asks about the needs of students and teachers for Sipirok local culture-based description text teaching material in learning the description text. The results obtained from these questions were obtained by 32 students answering the need for teaching materials based on Malay traditional marriage culture in the learning of description texts, while 4 students answering did not need teaching materials for the description of local culture-based Sipirok text in learning description text. that is because according to most students consider the textual teaching materials based on local culture Sipirok is an interesting teaching material in the learning activities of text description and very important culture is discussed again in learning in order to preserve and develop Sipirok Mandailing cultures that are almost lost, so students These consider Sipirok local culture-based text description teaching material needed by all students who love cultural preservation.

Different from the other four students who answered that they did not need teaching materials based on Sipirok local culture. According to them Sipirok local culture is already well known in his environment so that the student is not interested if it is discussed again in the process of learning the description text.

Based on the answers to the 3 question options above, it can be concluded that the student's environment influences the success of Sipirok local culture-based text description teaching material developed and Sipirok local culture-based text description teaching material successfully attracts the attention of students and is able to utilize students' cultural knowledge to understand the process learning done.

The results above are in accordance with the statement of Ginting (2005: 61), which states that the environment is a meaningful learning center and as a process of socialization and acculturation of abilities, as well as a center for the development of interests, so it can be concluded that culture in the environment around students is an effective means of adding interest student learning and be able to help students in the process of understanding learning activities. Students' knowledge of Sipirok local culture makes students more interested and understand the learning of description texts. 
Based on the theory cited by Umm Aisyah Siregar in a thesis entitled Pengembangan Media Pembelajaran Teks Prosedur Berbentuk Animasi Untuk Siswa Kelas VII SMP (2017: 106), an analysis of teacher needs is also carried out to see the characteristics of the teacher when teaching and the abilities that the teacher has as a facilitator for the process student learning.

In this study, the results of the teacher needs analysis were only based on 1 teacher of Indonesian language because of the limitations of schools that only had 1 teacher of Indonesian in class VII. The results of the questionnaire analysis of the need for teachers based on 3 question options stated that Indonesian language field teachers in grade VII of SMP Negeri 1 Sipirok Tapsel Regency needed teaching materials based on Sipirok local culture-based text.

In the first question, the teacher stated that he was not familiar with Sipirok local culture-based text description material. This is because the teacher has never seen a culturebased module on Indonesian language teaching materials in the 2013 curriculum which is text based. Then, in the second question, the teacher stated that he never used the Sipirok local culture-based description text teaching material on learning the description text.

However, the teacher had discussed about local culture such as Sipirok history, traditional tools of the Mandailing tribe and other traditional customs into the process of learning Indonesian, but not in learning the description text. Then in the third question, the teacher states that Sipirok local culture-based description text teaching materials are used in learning description text, because teaching materials in the form of modules can teach students to be more independent in learning and encourage students to be more active in asking questions and discussing about lessons.

Based on his three questions made to Habibah Nasution, S.Pd, as a teacher of Indonesian language in Junior High School 1 Sipirok at South Tapnuli Regency, it can be concluded that the Sipirok local culture-based learning module as the theme of text description learning in class VII makes students more interested and understand towards the learning of description text. Based on the experience of the teacher who has used Mandailing culture as teaching material for writing descriptions, the result is that students are more interested and motivated by learning.

In learning descriptive text, the teacher teaches students based on a handbook produced by the Ministry of Education and Culture. Based on the results of the literature survey, it was found that the teaching material used in the book titled "Indonesian Language" curriculum explained at this time is the 2013 curriculum which was revised in 2017. The learning themes in the book are free which set out some examples of guidelines in the use of electronic devices, and some tips in the process of daily activities. In contrast to the Sipirok local culture-based description text learning module that uses themes in each learning process with regard to the origin of Sipirok's history. The different themes can be seen in Figure below. 


\section{Bab \\ 1 Belajar \\ 1 Mendeskripsikan}

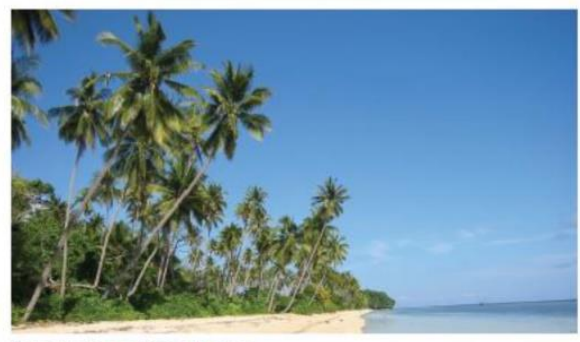

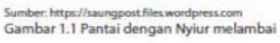

KOMPETENSI DASAR

3.1 Mengidentifikasi informasi dalam teks deskripsi tentang objek (sekola tempat wisata, tempat bersejarah, dan atau suasana pentas seni daerah

1 Mang didengar dan dibaca.
Menentukan isi teks deskripsi objek (tempat wisata, tempat bersejarah. pentass seni daerak, kain tradisional, dill) yang didengar dan dibaci. objek (sekolah, tempat wisata, tempat bersejarah, dan atau suasan pentas seni daerah) yang didengar dan dibaca.

4.2 Menyajikan data, gagasan, kesan dalam bentuk teks deskripsi tentan objek (sekolah, tempat wisata, tempat bersejarah, dan atau suasan struktur, kebahasaan baik secara lisan dan tulis.

Figure 1. Differences in the Theme of Text Descriptions Learning in Ministry of Education and Culture Book Production with Sipirok Local Culture-Based Text Learning Module

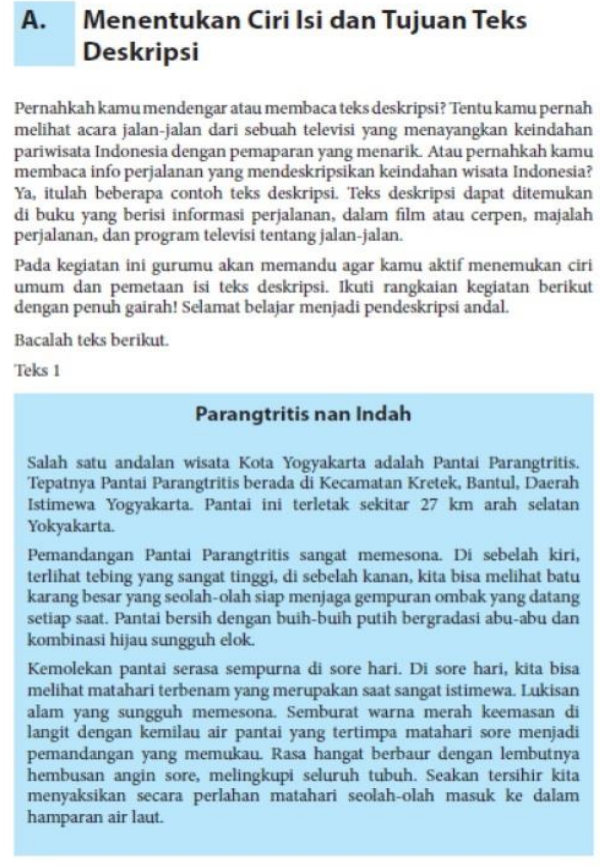

1. Mengidentifikasi Ciri Objek, Tujuan, dan Isi Teks Deskripsi Diskusikan dengan temanmu ciri teks deskripsi dari segi isi dan tujuan teks deskripsi!

\section{Teks Deskripsi}

Objek teks deskripsi bersifat khusus dengan ciri tertentu yang berbeda dengan umumnya. Daftarlah hal yang dideskripsikan dari keempat teks deskripsi sebelumnya.

\begin{tabular}{|c|l|}
\hline Teks & \multicolumn{1}{|c|}{ Objek/Hal yang Dideskripsikan } \\
\hline 1 & Pantai Parangtritis \\
\hline 2 & \\
\hline 3 & \\
\hline 4 & \\
\hline
\end{tabular}

Tujuan teks deskripsi menggambarkan objek dengan cara memerinci objek secara subjektif atau melukiskan kondisi objek dari sudut pandang penulis

Daftarlah tujuan yang akan dicapai dari keempat teks di atas!

\begin{tabular}{|c|l|}
\hline Teks & Tujuan \\
\hline 1 & menggambarkan keindahan Pantai Parangtritis \\
\hline 2 & \\
\hline 3 & \\
\hline 4 & \\
\hline
\end{tabular}

Figure 2. Example Text Descriptions in the Ministry of Education and Culture Book 
In contrast to the Sipirok local culture-based description text learning module that was developed, sample text descriptions are described based on the types of description text from the simplest to the most complex text types. After that, then an explanation of the learning material activities along with examples of the text. A sample of the Sipirok local culturebased description text learning module developed can be seen in Figure below.
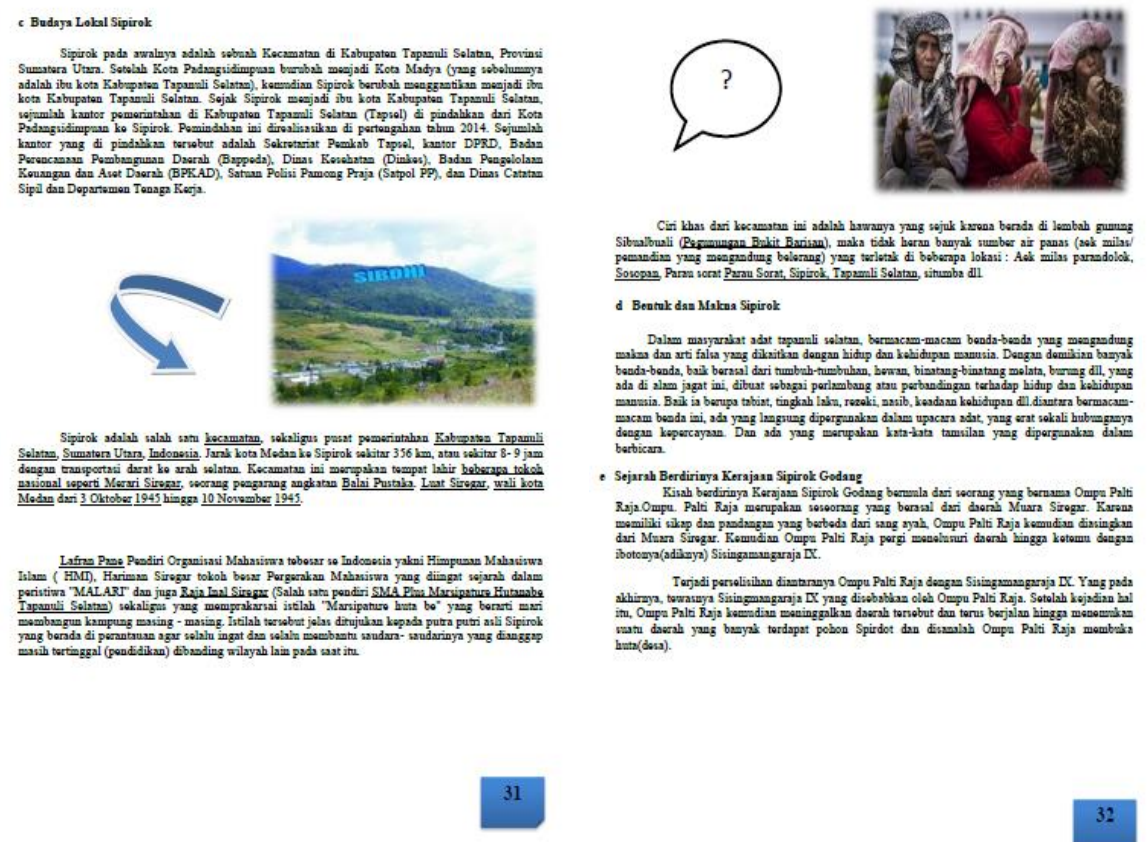

Figure 3. Example of Sipirok local culture-based description text learning module

Based on the results of the needs analysis, interview and literature survey described above, found the causes of the low ability of students to understand text learning procedures are as follows:

a) The presentation of teaching materials by teachers is only based on the Indonesian handbook given to teachers and students.

b) Lack of student understanding of the theme of learning material in Indonesian language learning textbooks.

c) The theme used in the Indonesian Language learning textbooks on education, while in the latest edition of the 2013 curriculum, the priority was on cultural themes.

The conclusion from the results of the literature study concluded that the Sipirok local culture-based learning module was more effectively used in learning the 2013 curriculum than only using Indonesian language learning books published by the government. This is in accordance with the 2013 curriculum learning reference which is based on a scientific approach is a student-centered approach so that students actively construct concepts, laws or principles through stages of observing, formulating problems, proposing or formulating hypotheses, collecting data with various techniques, analyzing data, draw conclusions and communicate concepts, laws or principles found. Thus the module as an independent teaching 
material for students is considered capable of achieving learning abilities in accordance with a scientific approach.

The feasibility of teaching materials is a tool used by researchers in measuring the appropriateness of a product of teaching materials developed as teaching materials used by students in the learning process. The eligibility criteria for teaching materials are items that can be used as a tool to examine the appropriateness of books / teaching materials. These criteria are general in nature so that they can be used to examine the feasibility of each book / module. These points include: content, presentation, language, and legibility, graphics, and national insights (Hartono, 2011: 3), Pusbuk and BSNP (in Hartono, 2011: 5) states there are four aspects that must be considered in choosing a book / teaching material, i.e. the appropriateness of content, presentation, linguistics, and graphics.

The results of the feasibility of teaching materials obtained based on stage II and stage III namely the initial product development and product trials. The initial product development that has been carried out is the validation of the content of the material and the design of the learning module products developed, the teacher's responses and student responses, as well as product revisions and the assessment and suggestions by material experts, design experts and teachers. The product trials carried out were the teaching material trials through 3 trial processes namely individual trials, small group trials, and limited field trials.

The initial product of the developed teaching material is a module-shaped teaching material in Sipirok local culture-based description text material for class VII. Based on the theory cited by Artifa Sorraya in the journal NOSI (214: 16), the description text teaching material consists of six main components, namely 1) the context development stage which contains theoretical learning material, 2) the text modeling stage which contains examples , 3) understanding exercises that contain questions that refer to BC indicators, 4) a brief summary of learning material, 5) evaluations that contain objective and subjective tests, and 6) reflections that contain students' impressions after carrying out the procedure text.

The results of the effectiveness of teaching materials obtained based on stage IV, namely student learning outcomes based on pretest and posttest. Student learning outcomes are obtained by giving a trial test using teaching materials that have been developed that aims to see the extent to which increased student understanding of text material description based on local culture Sipirok with using teaching materials developed in this study.

Based on the theory cited by Wenni, Ida, and Rustono in SELOKA Journal of Indonesian Language and Literature Education (2015: 101), the effectiveness of teaching materials can be seen from the results obtained by students and during the learning process as evidenced by the increase in the average score of learning outcomes the student. Student learning outcomes based on pretest and posttest show the difference in the difference from pretest to posttest the score obtained 10.42 with an average pretest 75.65 on the criteria of "good" and an average posttest of 90.8 on the criteria of "very good". It can be concluded that learning using on Sipirok local culture-based text descriptions can improve student learning outcomes in Indonesian language subjects especially description text material. 


\section{Conclusion}

The results of the development of Sipirok local culture-based text description teaching materials based on needs analysis state that the development of teaching materials is needed by teachers and students in the learning process to improve the quality of learning and align learning objectives with the latest curriculum provisions by the government and increase student interest in learning.

The results of the feasibility of Sipirok local culture-based text description teaching materials are qualified and suitable to be used as individual teaching materials with very good criteria, based on the assessment of material experts, instructional design experts, teacher and student responses.

\section{References}

Ali, Muhammad. (2000). Penelitian Kependidikan deskripsi dan Strategi. Bandung: Angkasa. Arifin, Syamsul dan Adi Kusrianto. 2009. Sukses Menulis Buku Ajar \& Referensi. Jakarta: PT Grasindo.

Amri, Sofan. (2013). Pengembangan \& Model Pembelajaran dalam Kurikulm 2013. Jakarta:

PT. Prestasi Pustakaraya

Albertus, Doni Koesoema. (2007). Pendidikan Karakter, Strategi Mendidik Anak di Zaman Global, Grasindo, Jakarta, September, 320 hlm. (Cetakan kedua tahun 2010).

Borg and Gall. (1983). Qualitative Research, Techniques and Procedures for Developing Grounded Theory, Sage Publications, International Educational and Profesional Publisher. London.

Butcher, Davies and Highton. (2006). Designing Learning: From Modul Outline to Effective Teaching. USA and Canada: Routledge.

Badan Pengkajian Pemvbangunan Sipirok. (1998). Sipirok na Soli. Medan: USU PRESS

Cut Nuraini, permukuman suku Batak Mandailing (Yogjakarta:Gajamada University Press, 2004)

Daryanto and Dwi Cahyono. (2014). Pengembangan Perangkat Pembelajaran. Yogyakarta: Gravanedia.

Daryanto. (2014). Pendekatan Pembelajaran Saintifik Kurikulum 2013. Yogyakarta: Gaya Media.

Daulay, Syahnan. (2017). Shift and Level of the Threatening of Lubu Siladang Language Extinction. International Journal of Language Learning and Applied Linguistics World (IJLLALW), Vol. 16, No. 4, (http:// www.ijllalw.org, Desember 2017)

Depdiknas. 2008. Panduan Pengembangan Bahan Ajar. Jakarta: Depdiknas

Diknas. 2004. Pedoman Umum Pengembangan Bahan Ajar. Jakarta: Ditjen Dikdasdenum.

Dinata, Nana Syaodih Sukma. 2015. Pengembangan Bahan Ajar Bahasa dan Sastra Indonesia. Medan: Kencana.

Dahiya Sunita \& Ajeya Jha. 2011. Training Need Assessment: A Critical Study. International Journal of Information Technology and Knowledge Management. January-June 2011, Volume 4, No. 1. 263-267. 
Dahliani \& Ispurwono. 2015. Local Wisdom in Built Environment in Globalization Era. International Journal of Education and Research Vol. 3 No. 6 June 2015.

Daryanto. 2013. Menyusun Modul: Bahan Ajar untuk Persiapan Guru dalam Mengajar. Yogjakarta: Gavamedia.

Depdiknas. 2002. Teknik Belajar dengan Modul. Jakarta: Dirjen Pendidikan Dasar dan Menengah.

Dinata, Nana Syaodih Sukma. 2015. Pengembangan Bahan Ajar Bahasa dan Sastra Indonesia. Medan:kencana.

Emzir. 2015. Metodologi Penelitian Pendidikan Kuantitatif \& Kualitatif. Jakarta: Rajawali Pers

Erma dwi citawati Ni Made. 2013. Pengembangan Materi Ajar Cerita Anak yang Mengandung Pendidikan Karakter pada Pembelajaran Membaca Cerita Anak SMP Kelas VII di Singaraja,

Emzir. 2015. Metodologi Penelitian Pendidikan Kuantitatif \& Kualitatif. Jakarta: Rajawali Pers.

Fajarini. 2014. Peranan Kearifan Lokal dalam Pendidikan Karakter. Jurnal Sosio Didaktika: Vol. 1, No. 2 Desember 2014.

Hamdani. 2011. Strategi Belajar Mengajar. Bandung: Pustaka

Hamid, Hamdani. 2013. Pengembangan Sistem Pendidikan di Indonesia. Bandung: Pustaka Setia.

Hamid, Hamdani. 2013. Pengembangan Sistem Pendidikan di Indonesia. Bandung: Pustaka Setia.

Koentjaraningrat. 1990. Manusia dan Kebudayaan di Indonesia. Jakarta: Djambatan.

Mahsun. 2014. Teks dalam Pembelajaran Bahasa Indonesia Kurikulum 2013. Jakarta: PT. Raja Grafindo Persada.

Majid, Abdul. 2011. Perencanaan Pembelajaran. Bandung: PT Remaja Rosdakarya.

Noor, Juliansyah. 2015. Metodologi Penelitian: Skripsi, Tesis, Disertasi dan Karya Ilmiah Jakarta: Kencana.

Nurdin \& Adrianto. 2016. Kurikulum dan Pembelajaran. Jakarta: PT. RajaGrafindo Persada.

Opara and Oguzor, Nkasiobi S. 2011. Instructional Technologies and School Curriculum in Nigeria: innovations and Challenges. Perspectives of Inovations, Economics \& Business Volume 7. Issue 1. 2011. ISSN 1804-0519.

Prastowo. 2012. Panduan Kreatif Membuat Bahan Ajar Inovatif (Menciptakan Metode Pembelajaran yang Menarik \& Menyenangkan). Yogyakarta: Diva Pers.

Puspitawati, dkk. 2011. Sistem Informasi Akutansi. Yogyakarta: Graha Ilmu

Putra, Nusa. 2011. Research \& Development (Penelitian Pengembangan: Suatu Pengantar). Jakarta: PT. RajaGrafindo Persada.

Riyana dan Susilana, Rudi. 2007. Media Pembelajaran: Hakikat, Pengembangan, Pemanfaatan, dan Penilaian. Bandung: CV. Wacana Prima

Rohani, Ahmad. 2010. Pengelolaan Pengajaran Sebuah Pengantar menuju Guru Profesional Jakarta: Rineka Cipta. 
Siregar, Daulay dan Hadi. 2017. The Development of Procedure Text Learning Media in the Form of Animation for Students of Class VII in SMP/MTS. Journal of Education and Practice. Vol. 8. No. 35. (http://www. iiste.org, 2017).

Suroso, et al. (2018). Performance Model of Kulcapi (Karo Musical Instrument) as a Teaching Material in Guitar Learning. Budapest International Research and Critics Institute (BIRCI-Journal), 1(4); 136-143.

Tesis (tidak diterbitkan). Singaraja: Program Pascasarjana Undiksha.

Zamzani. 2014. Eksistensi Bahasa Indonesia dalam Pendidikan Berbasis Keragaman Budaya. Pendidikan Bahasa dan seni, (OnLine), (http:// www. Staff.uny.ac.id). 